\title{
CECHY UZIARNIENIA VISTULIAŃSKICH ALUWIÓW W DOLINIE WARTY, KOTLINA KOLSKA
}

\author{
Grain size composition of the Vistulian alluvium in the Warta River valley, Koło Basin
}

\author{
MATEUSZ LISEK*, JOANNA PETERA-ZGANIACZ**
}

\begin{abstract}
Zarys treści. Badania osadów vistuliańskich wypełniających dolinę Warty wykonano w odkrywkach Koźmin Północ (Kwiatków) oraz Koźmin (Południe) PAK KWB „Adamów”. Uzasadnieniem podjęcia badań była możliwość poznania cech uziarnienia osadów dużej rzeki nizinnej w pobliżu osi doliny, w profilach sięgających podłoża przedvistuliańskiego, a celem rozpoznanie etapów depozycji osadów oraz warunków hydrodynamicznych panujących podczas ich akumulacji. W badanych profilach wyodrębniono siedem jednostek depozycyjnych. Najbardziej rozbudowaną jednostkę podzielono na kilka subjednostek. Wyniki analizy uziarnienia posłużyły do wyliczenia wskaźników Folka i Warda, które stały się podstawą wnioskowania na temat zróżnicowania dynamiki procesów sedymentacyjnych. Wykazano, że depozycja badanych aluwiów zachodząca od schyłku środkowego plenivistulianu do późnego vistulianu następowała w cyklicznie, choć nie radykalnie, zmieniających się warunkach przepływu od względnie wysokoenergetycznych po niskoenergetyczne. W późnym vistulianie i holocenie akumulowane były osady w dwóch wyraźnie wyodrębniających się facjach: korytowej i pozakorytowej, przy znacznym udziale materii organicznej w aluwiach.
\end{abstract}

Słowa kluczowe: aluwia, wskaźniki uziarnienia, warunki hydrodynamiczne, plenivistulian, późny vistulian, Polska Środkowa

Abstract. Vistulian deposits which fill the Warta River valley were studied in the open pits Koźmin North (Kwiatków) and Koźmin (South) of the "Adamów" Lignite Mine. The studies were conducted due to the possibility of analysing fluvial deposits of a big lowland river close to the axis of the valley, in profiles which reach a pre-Vistulian background. The aim of the research was to establish the phases of deposition and hydrodynamic conditions during the accumulation. In the studied profiles, seven depositional units have been distinguished, and one of them - the thickest - was divided into seven subunits. The results of the grain size analysis were used to calculate the Folk and Ward coefficients, as the basis for interpretations of differentiation in sedimentary environment dynamics. The deposition, which took place from the end of the Middle Plenivistulian to the Late Vistulian, was characterized by cyclic, but rather mild, transitions from rather high energetic to low energetic conditions. During the Late Vistulian and Holocene, alluvium has been accumulated in two clearly distinguishing facies: channel and overbank, with high content of organic matter.

Key words: alluvium, grain size composition coefficients, hydrodynamic conditions, Plenivistulian, Late Vistulian, Central Poland

\section{Wprowadzenie}

Osady rzeczne utworzone podczas vistulianu są powszechnie dokumentowane w dolinach rzecznych strefy staroglacjalnej, a ich cechy strukturalne i teksturalne dobrze rozpoznane. W większości badanych profili stwierdzano względne zwiększanie frakcji deponowanych osadów przy przejściu od środkowego do górnego plenivistulianu (m.in. Krzemiński 1965; Turkowska 1988, 1995; Harasimiuk 1991), co wiązało się z wykształceniem roztokowych koryt rzecznych (m.in. Kozarski 1983; Rotnicki, Młynarczyk 1989; Turkowska 1997; Petera 2002; Petera-Zganiacz 2007). Niejednokrotnie $w$ osadach środkowego plenivistulianu, deponowanych w dolinach rzecznych, stwierdzano obecność poziomów organicznych, które ułatwiały lokowanie kolejnych etapów rozwoju dolin rzecznych w czasie, szczególnie w przypadkach, kiedy wiek poziomów organicznych mieścił się w zasięgu metody ${ }^{14} \mathrm{C}$ (Pazdur i in. 1980; Krzyszkowski 1990; Manikowska 1996; Petera 2002; Forysiak 2005). Z kolei za powszechną cechę aluwiów

\footnotetext{
* Pracownia Geologiczno-Inżynierska sp. z o.o. sp.k., ul. Obywatelska 102/104, 94-104 Łódź; e-mail: matfox@ interia.pl

** Uniwersytet Łódzki, Wydział Nauk Geograficznych, Katedra Geomorfologii i Paleogeografii, ul. Narutowicza 88, 90139 Łódź; e-mail: joanna.petera@geo.uni.lodz.pl
} 
górnego plenivistulianu uważa się brak materii organicznej (Krzyszkowski 1990; Goździk 1995; Goździk, Zieliński 1999). Następujące u schyłku vistulianu istotne zmiany w dolinach rzecznych, będące skutkiem adaptacji do łagodniejszych warunków klimatycznych, spowodowały zmianę układu koryt rzecznych na wielkomeandrowe (m.in. Turkowska 1988; Rotnicki, Młynarczyk 1989; Starkel 1991; Kamiński 1993; Kobojek 2000) lub wielokorytowe (Superson 1996; Turkowska i in. 2000; Forysiak 2005; Petera-Zganiacz i in. 2015), a wreszcie na meandrowe (m.in. Kozarski 1983; Turkowska 1988; Kamiński 1993; Kobojek 2000), co przyczyniło się do zmiany w uziarnieniu osadów rzecznych na bardziej zróżnicowane, z wyraźniej wyodrębniającymi się cechami granulometrycznymi osadów korytowych i pozakorytowych, przy coraz większym udziale materii organicznej w aluwiach (m.in. Turkowska 1990).

Zdefiniowanie ogólnych prawidłowości rozwoju dolin rzecznych w vistulianie było możliwe dzięki wieloletnim badaniom, które prowadzono w dostępnych odsłonięciach zlokalizowanych najczęściej na terasach rzecznych. Prace te często obarczone były oczywistymi ograniczeniami technicznymi, wynikającymi $\mathrm{z}$ braku możliwości wglądu w pełne profile osadów wypełniających doliny. Szczególne możliwości stwarzały duże odsłonięcia kopalniane takie jak odkrywki KWB „Bełchatów” czy PAK KWB „Adamów”. Utworzenie odkrywki Koźmin Północ (Kwiatków) w dolinie Warty, niedaleko współczesnego koryta tej dużej rzeki nizinnej, dało wyjątkową okazję prowadzenia badań osadów wypełniających dolinę w pełnym profilu, w pobliżu jej osi.

Celem badań było poznanie wybranych cech teksturalnych osadów vistuliańskich wypełniających dolinę Warty w jej środkowej części, poprzez powiązanie wydzielonych $\mathrm{w}$ kilku badanych profilach jednostek i subjednostek depozycyjnych oraz zdefiniowanie ich wspólnych cech uziarnienia, jak również wskazanie etapów akumulacji aluwiów od środkowego plenivistulianu po holocen.

\section{Metody i materiały}

Terenowa część prac polegała na wytypowaniu stanowisk badawczych w miejscach, które potencjalnie dawały perspektywy opracowania pełnych profili osadów fluwialnych, przy czym jeden z profili znajdował się zaledwie $500 \mathrm{~m}$ od współczesnego koryta Warty. Profile zostały opró- bowane metodą punktową przy zastosowaniu zasady poboru materiału do analiz laboratoryjnych z warstw o odmiennych cechach strukturalnych i teksturalnych określonych na podstawie oceny makroskopowej (Mycielska-Dowgiałło 1995; Rutkowski 1995). Pobrane próbki osadu poddano analizie granulometrycznej, dla grubszej frakcji osadu stosowano metodę sitową, a oznaczenie składu granulometrycznego materiału drobnofrakcyjnego wykonano metodą areometryczną (PN-R04032, 1998).

$\mathrm{Na}$ podstawie wyników analiz laboratoryjnych, przy zastosowaniu pakietu Gradistat wyliczono wskaźniki Folka i Warda (1957): średnią średnicę ziarna $\left(\mathrm{M}_{\mathrm{Z}}\right)$, wysortowanie osadu $\left(\delta_{1}\right)$ i skośność $\left(\mathrm{Sk}_{1}\right)$. Kurtoza została pominięta z uwagi na jej poboczną rolę $\mathrm{w}$ analizie uziarnienia osadów, która sprowadza się do uzupełnienia wskaźnika skośności (Brodzikowski 1992). Wskaźniki uziarnienia posłużyły do skonstruowania diagramów relacji między wysortowaniem i średnią średnicą ziarna oraz między skośnością i średnią średnicą ziarna, co było pomocne przy identyfikacji facji analizowanych osadów rzecznych (Mycielska-Dowgiałło, Ludwikowska-Kędzia 2011; Szmańda 2011).

Vistuliańskie aluwia Warty analizowano łącznie w trzech profilach oznaczonych symbolami: D, O/K i S (rys. 1).

Profil D znajdował się około $1800 \mathrm{~m}$ na zachód od współczesnego koryta Warty i obejmował 17,51 m osadów, licząc od powierzchni terenu o wysokości 97,5 m n.p.m.:

- od 17,51 m do 17,30 m-żwiry,

- od 17,30 m do 2,00 m - piaski średnioi drobnoziarniste, piaski z mułami i muły piaszczyste barwy od jasnoszarej do beżowej; na głębokości $15,60 \mathrm{~m}$ do $15,55 \mathrm{~m}$ znajduje się przewarstwienie organiczno-mułowe,

- od 2,00 m do 1,52 m - seria organiczno-mineralna o barwie ciemnobrunatnej do czarnej,

- od 1,52 m do $0,30 \mathrm{~m}$ - piaski drobnoziarniste, piaski z mułami,

- od 0,30 m do powierzchni terenu - osady piaszczyste $\mathrm{z}$ widocznymi śladami procesów glebowych i humus.

Profil $\mathrm{O} / \mathrm{K}$ położony był około $1300 \mathrm{~m}$ na północny wschód od profilu D i około $500 \mathrm{~m}$ od współczesnego koryta Warty. Sięgał 18,23 m w głąb, licząc od powierzchni terenu o wysokości 96 m n.p.m. i obejmował:

- od 18,23 m do 16,93 m - piaski drobnoi średnioziarniste barwy jasnobeżowej,

- od 16,93 m do 16,55 m - glina zwałowa barwy szarej, silnie zdeformowana, 


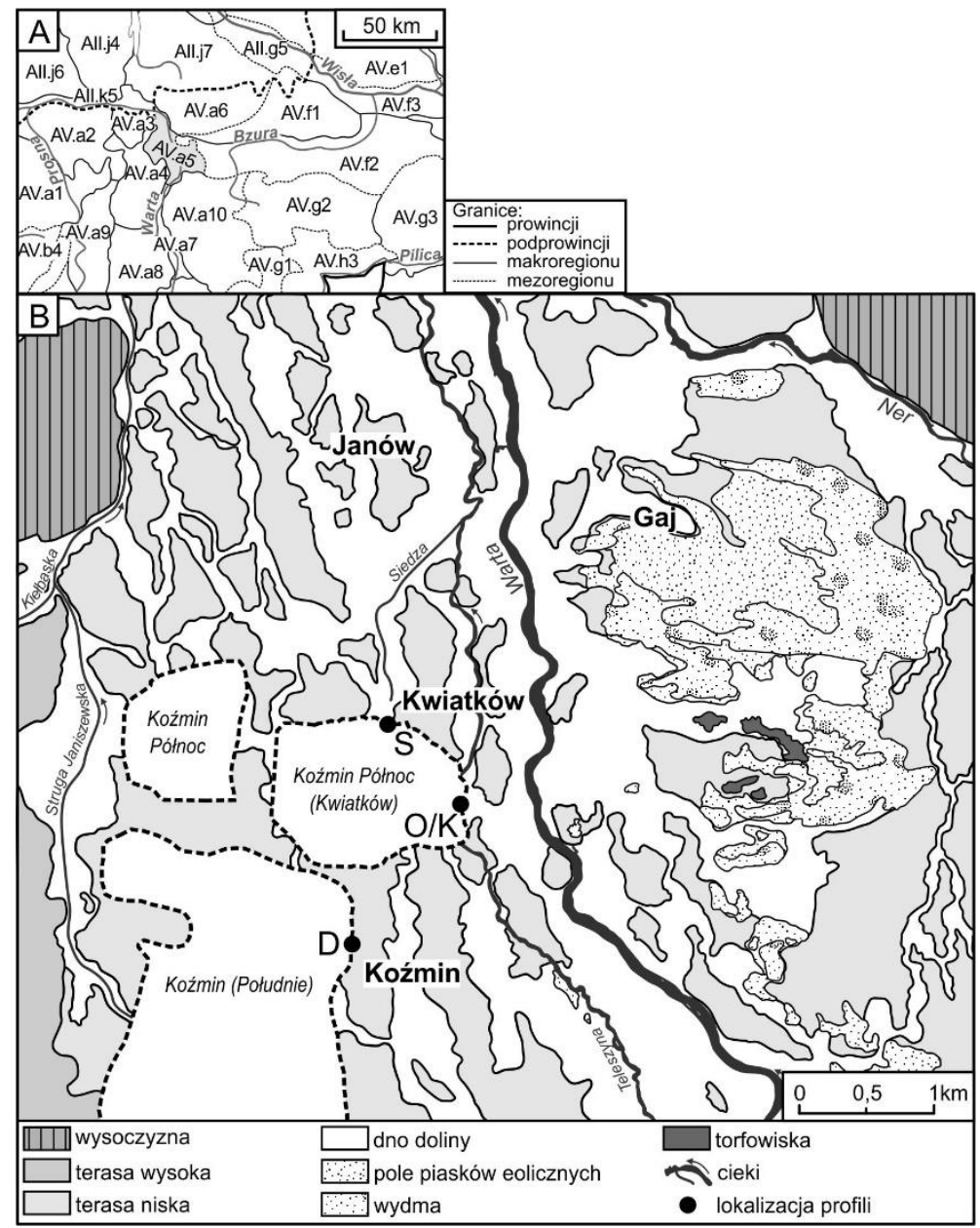

Rys. 1. Położenie terenu badań

A - Położenie Kotliny Kolskiej na tle podziału Polski na jednostki geomorfologiczne wg Gilewskiej (1991) B - Położenie badanych profili na tle sytuacji geomorfologicznej (wg Forysiaka 2005)

Location of the study area

A - Location of the Koło Basin in relation to the geomorphological units by Gilewska (1991)

B - Location of studied profiles in relation to geomorphological situation (after Forysiak 2005)

- od 16,55 m do 15,65 m - żwir piaszczysty, szary,

- od $15,65 \mathrm{~m}$ do $6,56 \mathrm{~m}$ - piaski średnioi drobnoziarniste, piaski z mułami i muły piaszczyste, o barwach od jasnoszarej do beżowej,

- od 6,56 m do 5,56 $\mathrm{m}$ - piaski drobnoziarniste, jasnobeżowe,

- od 5,56 m do $0,6 \mathrm{~m}-\mathrm{w}$ spągu piaski ze żwirami, piaski średnio- i drobnoziarniste, piaski $\mathrm{z}$ mułami, namuły organiczne,

- od 0,6 m do powierzchni terenu - osady piaszczyste $\mathrm{z}$ widocznymi śladami procesów glebowych i humus.

Profil S znajdował się około $800 \mathrm{~m}$ na północny zachód od profilu $\mathrm{O} / \mathrm{K}$ i około $1100 \mathrm{~m}$ od współczesnego koryta Warty. Obejmował 16,20 $\mathrm{m}$ osadów, licząc od powierzchni terenu o wysokości 95,3 m n.p.m.:
- od 16,20 m do 3,77 m - piaski średnioi drobnoziarniste, piaski z mułami, muły piaszczyste o barwie beżowej lub rzadziej szarej, na głębokości 15,05-15,12 m występuje warstwa zawierająca namytą materię organiczną,

- od 3,77 do 0,50 - piaski średnioziarniste, rzadziej drobnoziarniste i piaski z mułami o barwie beżowej,

- od 0,50 m do powierzchni terenu - piasek humusowy $\mathrm{z}$ widocznymi procesami glebowymi o barwie ciemnobeżowej;

\section{Teren badań}

Teren badań zlokalizowany jest, zgodnie z podziałem Polski na jednostki geomorfologiczne według Gilewskiej (1991), w południowo-zachodniej części mezoregionu o nazwie Kotlina Kolska 
(AV.a5) (rys. 1A), który swój charakter zawdzięcza rozszerzeniu doliny Warty w miejscu połączenia $\mathrm{z}$ pradoliną warszawsko-berlińską. Kotlinę Kolską otaczają wyraźnie zarysowane w rzeźbie wysoczyzny: Turecka (AV.a4), Kłodawska (AV.a6) i Wzgórza Złotogórskie (AV.a3) oraz mezoregiony o mniej urozmaiconym ukształtowaniu terenu takie jak Wysoczyzna Łaska (AV.a10) i Wysoczyzna Kłodawska (AV.a6). Poprzez dolinę Warty Kotlina Kolska łączy się od północnego zachodu z Doliną Konińską (AII.k5) oraz z Kotliną Sieradzką (AV.a7) od południa, a na wschodzie nawiązuje do niej Równina Łowicko-Błońska (AV.f2), odwadniana w zachodniej części przez Ner, prawobrzeżny dopływ Warty. Kotlina Kolska jest zaliczana do makroregionu Niziny Południowowielkopolskiej (AV.a) i podprowincji - Nizin Środkowopolskich (AV). Jej obszar włączony został przez Turkowską (2006) do regionu łódzkiego, wyznaczając jego północno-zachodni kraniec.

Kotlina Kolska znajduje się w zasięgu zlodowaceń środkowopolskich. Po raz ostatni przykryta była lądolodem warty, ale najważniejsze elementy jej budowy geologicznej i rzeźby ukształtowały się podczas zlodowacenia wisły. Maksymalny zasięg tego zlodowacenia $\mathrm{w}$ fazie poznańskiej znajdował się na północno-zachodnim krańcu kotliny (Stankowski, Krzyszkowski 1991; Marks i in. 2006).

Badania przeprowadzono $\mathrm{w}$ centralnej części Kotliny Kolskiej po zachodniej stronie doliny Warty, gdzie dominującą formą rzeźby jest szeroka na kilka kilometrów terasa niska porozcinana licznymi korytami, w większości niefunkcjonujących już cieków (rys. 1B). Jej powierzchnia znajduje się na wysokości od około 98 do 95 m n.p.m. i wznosi się ponad dno doliny na 1-2 m. Niektóre płaty terasy nadbudowane są 1-2-metrowymi pokrywami eolicznymi. Obecnie rzeźba Kotliny Kolskiej jest silnie przekształcona antropogenicznie, głównie na skutek odkrywkowej eksploatacji węgla brunatnego przez PAK KWB „Adamów”. Szczegółowe analizy uziarnienia osadów wykonano w odkrywce Koźmin Północ (Kwiatków) (rys. 1B), gdzie wytypowano profile $\mathrm{O} / \mathrm{K}$ i S (Lisek 2017) oraz w zrekultywowanej już odkrywce Koźmin (Południe), w której zlokalizowany jest profil D (Petera-Zganiacz 2007).

\section{Wyniki badań}

Analiza osadów udokumentowanych w trzech badanych profilach pozwoliła na wydzielenie siedmiu jednostek sedymentacyjnych (A, B, C, D,
$\mathrm{E}, \mathrm{F}, \mathrm{G})$ różniących się od siebie pod względem litologicznym i genetycznym, a w niektórych przypadkach jednostki oddzielone są wyraźnymi granicami erozyjnymi.

Najwięcej $\mathrm{z}$ wydzielonych jednostek sedymentacyjnych stwierdzonych zostało $\mathrm{w}$ profilu $\mathrm{O} / \mathrm{K}$. Piaski znajdujące się w dolnej części profilu przypisano do jednostki A. Należy brać pod uwagę, że analizie poddana była tylko stropowa, być może niewielka część tej jednostki sedymentacyjnej, nie udokumentowano bowiem jej spągu. Wartość średniej średnicy ziarna dla większości próbek jest zbliżona i wynosi około 2 phi, choć w jednym przypadku wzrosła do 6,759 phi. Pozostałe $\mathrm{z}$ analizowanych wskaźników mieszczą się w granicach: skośność od $-0,384$ do 0,161 a wysortowanie od 0,334 do 1,321. Z przeprowadzonej analizy wynika, że osady jednostki A to głównie piaski średnioziarniste $\mathrm{z}$ pojedynczymi przewarstwieniami mułowymi, których skośność zawiera się w przedziale rozkładu symetrycznego, a wysortowanie jest dobre do bardzo dobrego (rys. 2).

Glina zwałowa należąca do jednostki B jest masywna, a w jej spągu utworzyły się pogrązy angażujące $\mathrm{w}$ deformacje piaski podścielające glinę. Amplituda struktur deformacyjnych wynosi od 15 do $25 \mathrm{~cm}$. Granica między gliną jednostki B i żwirowo-piaszczystą jednostką C ma charakter erozyjny. Miąższe na $90 \mathrm{~cm}$ osady żwirowo-piaszczyste nie wykazują warstwowania i najprawdopodobniej stanowią rezyduum po zniszczeniu części pokładu gliny.

Najbardziej rozbudowana jest jednostka sedymentacyjna $\mathrm{D}$ o miąższości osiągającej $\mathrm{w}$ profilu $\mathrm{O} / \mathrm{K} 9,9 \mathrm{~m}$, w profilu $\mathrm{S} 12,4 \mathrm{~m}$ i $15,3 \mathrm{~m}$ w profilu D. Duża miąższość oraz zaznaczające się cykliczne zróżnicowanie osadów jednostki D we wszystkich profilach pozwoliło na wydzielenie siedmiu subjednostek sedymentacyjnych (rys. 2). Dokonując podziału, brano pod uwagę przede wszystkim różnice w uziarnieniu osadów, ale także kierowano się cechami strukturalnymi, które pozwoliły na precyzyjne wskazanie granic.

Zestawienie wartości średniej średnicy ziarna ze wskaźnikami wysortowania oraz skośności dla jednostki D pokazuje, że zdecydowana większość populacji próbek zawiera się we wspólnej grupie. Biorąc pod uwagę relację skośności i średniej średnicy ziarna wspólną grupę stanowi 79\% populacji próbek pobranych z profilu $\mathrm{O} / \mathrm{K}, 84 \%$ z profilu S i 77\% z profilu D (rys. 3A). Relacja wysortowania do średniej średnicy ziarna wykazuje równie silne powiązania, ponieważ we wspólnej grupie znajduje się $88 \%$ populacji próbek z profilu $\mathrm{O} / \mathrm{K}$, $78 \%$ z profilu S oraz $83 \%$ z profilu D (rys. $3 \mathrm{~B}$ ). 


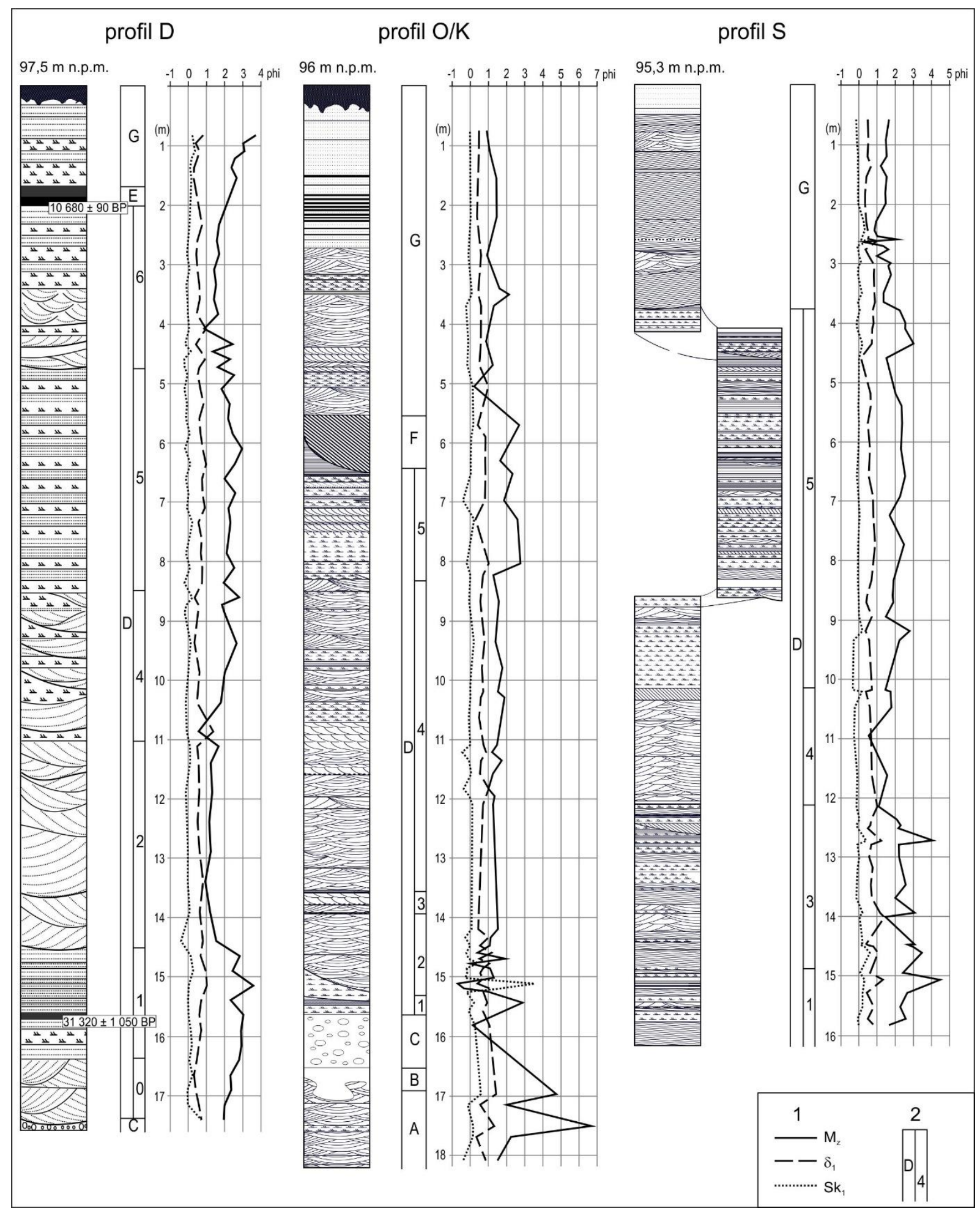

Rys. 2. Zestawienie badanych profili

1 - jednostki i subjednostki depozycyjne, 2 - wskaźniki Folka i Warda (1957)

Composition of studied profiles

1 - depositional units and subunits, 2 - Folk and Ward (1957) coefficients 


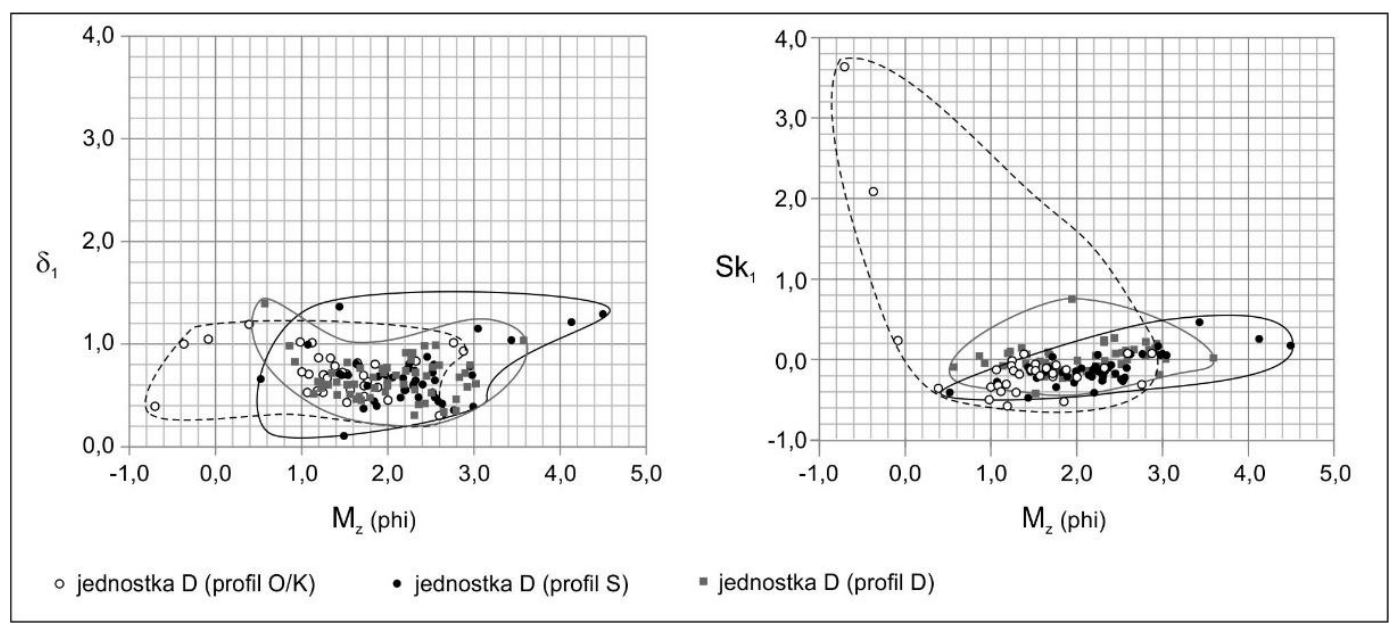

Rys. 3. Relacja średniej średnicy ziarna i wysortowania oraz średniej średnicy ziarna i skośności osadów jednostki D

Relationship between mean grain size and sorting degree and between mean grain size and skewness of deposits of the unit D

Średnia średnica ziarna dla jednostki D w profilu $\mathrm{O} / \mathrm{K}$ zawiera się $\mathrm{w}$ przedziale od 0,701 do 2,883 phi, w profilu D od 0,572 do 3,592 phi, a w profilu $S$ granice te są szersze ze względu na udział drobniejszej frakcji i oscylują między 0,526 a 4,501 phi (rys. 2,3). Zaznaczyć należy, że wartości tego wskaźnika pokazują wyraźnie dominujący udział frakcji piaszczystej, mieszczący się najczęściej w granicach między 1 a 2,5 phi. Wysortowanie osadów jednostki $\mathrm{D}$ w profilu $\mathrm{O} / \mathrm{K}$ zawiera się w granicach od 0,302 do 1,101 , w profilu $\mathrm{S}$ od 0,106 do 1,364 , a w profilu D od 0,306 do 1,378. Wartości te informują o wysortowaniu utworów od bardzo dobrego do słabego, jednak biorąc pod uwagę dominujące wyniki, z pominięciem wartości skrajnych, osady te należy uznać za dobrze i średnio wysortowane. Ostatnia $z$ analizowanych miar to skośność. Jej wartości $\mathrm{w}$ profilu $\mathrm{O} / \mathrm{K}$ zawierają się $\mathrm{w}$ przedziale od $-0,45$ do 3,73 , w profilu $\mathrm{S}$ od $-0,348$ do 0,59 , a w profilu D od $-0,4$ do 0,723 . Nieznacznie przeważają wartości ujemne dla poszczególnych próbek, wskazując przewagę frakcji gruboziarnistej nad frakcją o maksymalnej częstości. Analiza wskaźników uziarnienia w odniesieniu do całej jednostki D pozwala na uzyskanie jedynie ogólnego obrazu cech osadów. Dopiero prześledzenie wartości wskaźników w obrębie wyraźnie wyodrębniających się subjednostek ukazuje istotne cechy osadu, charakteryzujące warunki depozycji.

Subjednostka D0 o miąższości około 1 metra udokumentowana została jedynie w profilu D (rys. 2). Reprezentowana jest przez przekątnie warstwowane piaski średnio- i drobnoziarniste (1,962,37 phi), odznaczające się najczęściej dobrym wysortowaniem.
Subjednostka D1 została zaobserwowana w profilach S, D i O/K, gdzie jej miąższość wynosi odpowiednio: niespełna $1,5 \mathrm{~m}, 2 \mathrm{~m}$ oraz $0,7-0,3 \mathrm{~m}$ (rys. 2). W osadach odnotowano małoskalowe, niskokątowe warstwowania przekątne, przechodzące w riplemarkowe i horyzontalne, jak również warstewki masywne. Cechą charakterystyczną subjednostki D1 jest obecność przewarstwienia $\mathrm{z}$ udziałem materiału organicznego, które w profilu D przybiera postać masywnego osadu mułowo-organicznego o miąższości $5 \mathrm{~cm}$, a w profilu $\mathrm{S}$ występuje jako nagromadzenie materii organicznej w obrębie $7 \mathrm{~cm}$ warstewki piaszczysto-mułowej o laminacji riplemarkowej. Datowanie metodą radiowęglową osadu mułowo-organicznego w profilu D dało wynik $31320 \pm 1050{ }^{14} \mathrm{C}$ BP (Lod 1403) (Petera-Zganiacz 2007). W profilu O/K subjednostka D1 została w znacznym stopniu zerodowana, co uniemożliwia potwierdzenie, czy i w tym przypadku obecna była warstwa wzbogacona w materiał organiczny.

Średnia średnica ziarna dla osadów subjednostki D1 w profilu S zawiera się w przedziale od 1,636 do 4,501 phi, w profilu D od 2,334 do 3,592 phi, a profil O/K reprezentowany jest przez zaledwie dwie próbki, z których uzyskano wartości: 1,750 phi oraz 2,955 phi (rys. 2, 4). Granice podanych przedziałów wskazują na frakcję od piasków średnioziarnistych do bardzo gruboziarnistego pyłu, ale większość materiału reprezentuje frakcję piasków drobnych (rys. 2, 4). Osady subjednostki D1 odznaczają się wysortowaniem dobrym do średniego (profil S: od 0,418 do 1,291; profil D: od 0,458 do 1,021 ; profil $\mathrm{O} / \mathrm{K}$ 0,7 i 0,94 ), przy czym w przypadku profilu D wysortowanie osadu, przy nieco mniejszej średnicy ziarna, jest lepsze niż 
w profilu S. Współczynnik skośności wyliczony dla osadów w profilu $\mathrm{S}$ mieści się $\mathrm{w}$ granicach od $-0,084$ do 0,301 , a w profilu D między $-0,012$ a 0,261 . W większości próbek miara ta przyjmuje wartości dodatnie, natomiast $\mathrm{w}$ profilu $\mathrm{O} / \mathrm{K}$ skośność równa jest -0,03 i 0,1.

Subjednostkę D2 udokumentowano w profilach $\mathrm{O} / \mathrm{K}(1,4 \mathrm{~m}$ miąższości) i $\mathrm{D}$ (3,5 m miąższości). Składają się na nią wyłącznie osady mineral- ne, wyraźnie grubsze niż miało to miejsce w subjednostce D1, warstwowane przekątnie z niewielkim udziałem warstwowania horyzontalnego. Średnia średnica ziarna oscyluje od -0,701 do 2,01 phi w profilu O/K i 0,932 do $1,671 \mathrm{w}$ profilu $\mathrm{D}$, wskazując na dominację frakcji piasków gruboziarnistych i średnioziarnistych (rys. 2, 5). Wysortowanie osadu w profilu $\mathrm{O} / \mathrm{K}$ jest zróżnicowane od dobrego do słabego $(0,393$ do 1,191), podczas gdy

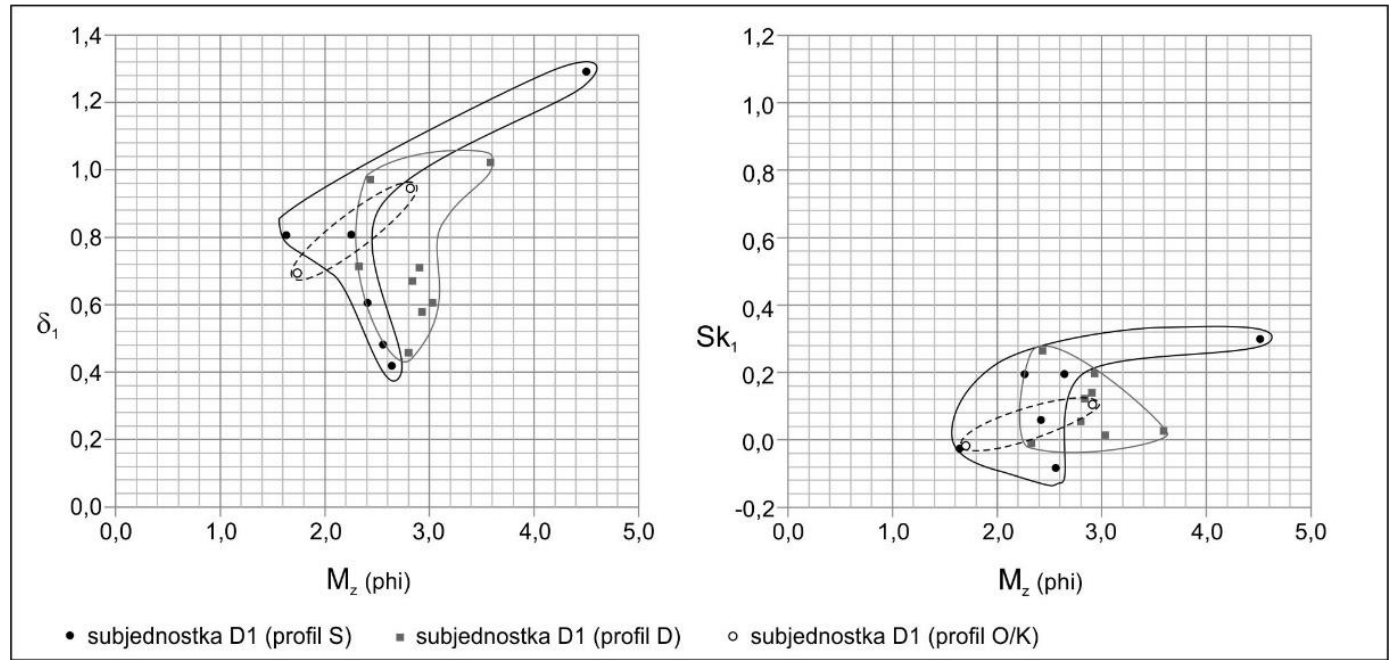

Rys. 4. Relacja średniej średnicy ziarna i wysortowania oraz średniej średnicy ziarna i skośności osadów subjednostki D1

Relationship between mean grain size and sorting degree and between mean grain size and skewness of deposits of the subunit D1

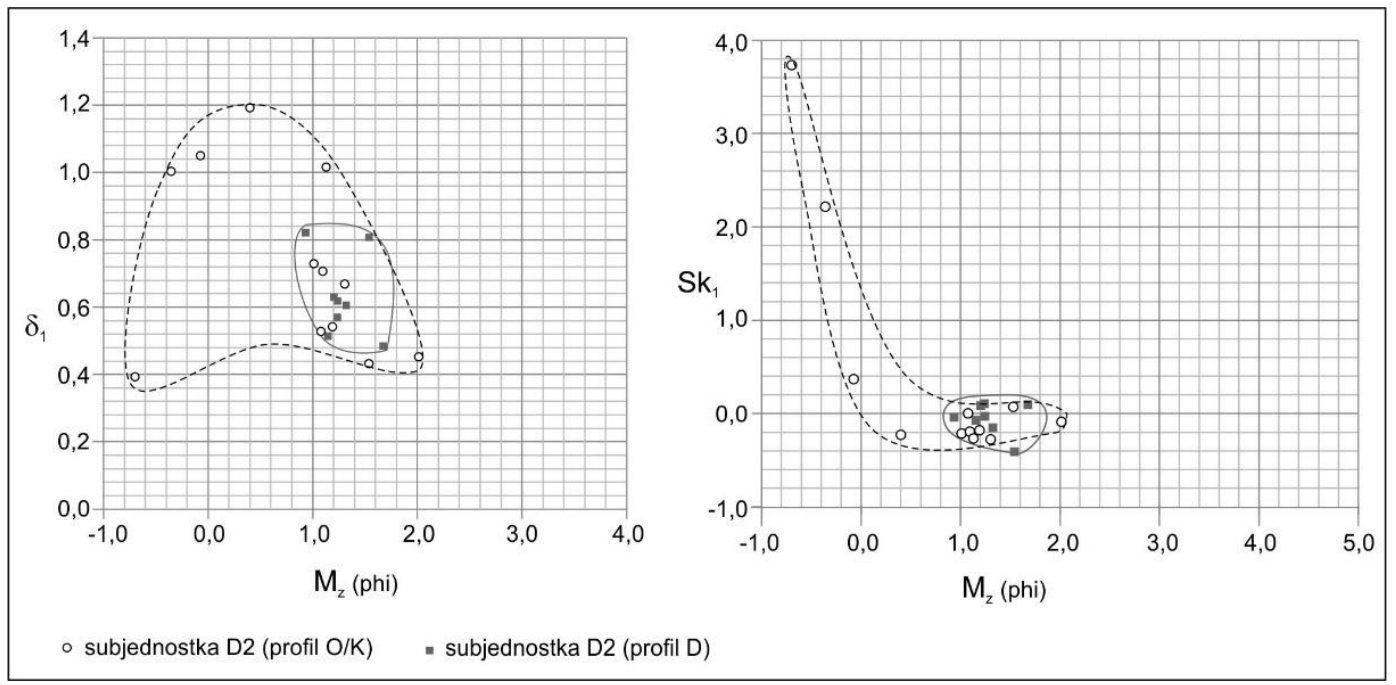

Rys. 5. Relacja średniej średnicy ziarna i wysortowania oraz średniej średnicy ziarna i skośności osadów subjednostki D2

Relationship between mean grain size and sorting degree and between mean grain size and skewness of deposits of the subunit D2 
W większości próbek z profilu D odznacza się wysortowaniem średnim $(0,482$ do 0,817$)$. Skośność informuje o przewadze frakcji grubszej nad najczęściej występującą (rys. 5), mieszcząc się w granicach od $-0,281$ do 3,73 , przy czym znaczne wartości dodatnie obserwowane są w spągu subjednostki D2 w profilu O/K. Wartości te w profilu D odznaczają się znacznie większą koncentracją w granicach od -0,4 do 0,101.

Subjednostka D3 w profilu O/K (rys. 2) oddzielona jest od subjednostki D2 powierzchnią erozyjną, a w strukturze osadów dominują warstwowania przekątne i horyzontalne. W profilu $\mathrm{S}$ analizowana subjednostka jest dobrze wykształcona i obejmuje 2,7 m osadów, odznaczających się małoskalowym warstwowaniem przekątnym, laminacją riplemarkową i horyzontalną. $\mathrm{W}$ osadach tych stwierdzono ślady obecności niewielkich sezonowych szczelin mrozowych. Wskaźniki uziarnienia osadu pokazują dominację frakcji piasku drobnoziarnistego z udziałem piasku bardzo drobnego (1,45 do 4,13 phi) (rys. 2), odznaczającego się wysortowaniem od dobrego do słabego $(0,39$ do 1,37$)$. Wartości miary skośności, pomimo tego że mieszczą się w niezbyt szerokim przedziale (od$0,15$ do 0,59$)$, są względnie zróżnicowane. Zaznacza się wzbogacenie grubszej frakcji w ziarna większe od najczęściej występujących, a wskaźnik skośności dla drobniejszego materiału pokazuje ponadprzeciętny udział frakcji o większych wartościach phi.

Kolejna subjednostka (D4) manifestuje się we wszystkich trzech profilach. Najbardziej rozbudowana jest $\mathrm{w}$ profilu $\mathrm{O} / \mathrm{K}$, gdzie osiąga miąższość $5,3 \mathrm{~m}$, a w profilach $\mathrm{D}$ i $\mathrm{S}$ odpowiednio $2,3 \mathrm{~m}$ i $2 \mathrm{~m}$. Kontakt osadów subjednostki D4 z materiałem podścielającym ma charakter erozyjny. W strukturze osadu dominuje warstwowanie przekątne rynnowe o średniej skali, przy niewielkim udziale warstwowania przekątnego tabularnego i laminacji riplemarkowej. Średnia średnica ziarna dla profilu O/K oscyluje od 0,985 do 1,886 phi, w profilu D od 0,572 do 2,666 phi, a w profilu $\mathrm{S}$ od 0,526 do 1,768 phi (rys. 2, 6) i wskazuje na dominujący udział frakcji piasku średnioziarnistego i gruboziarnistego. Osady odznaczają się średnim wysortowaniem, a tylko w pojedynczych próbkach w każdym z profili wysortowane są dobrze, co potwierdzają wartości wskaźnika $\delta_{1}$ dla profili: $\mathrm{O} / \mathrm{K}$ od 0,49 do 1,019 , D od 0,336 do 1,378 oraz $\mathrm{S}$ od 0,373 do 0,996 . Współczynnik skośności dla profilu $\mathrm{O} / \mathrm{K}$ mieści się $\mathrm{w}$ granicach od $-0,45$ do 0,195 , dla profilu D od $-0,204$ do 0,125 , a dla profilu $S$ od $-0,348$ do 0,162 . Dla większości próbek ze wszystkich profili uzyskano ujemne wartości współczynnika skośności, wskazujące na zwiększony udział frakcji grubszej niż najczęściej występująca (rys. 6).

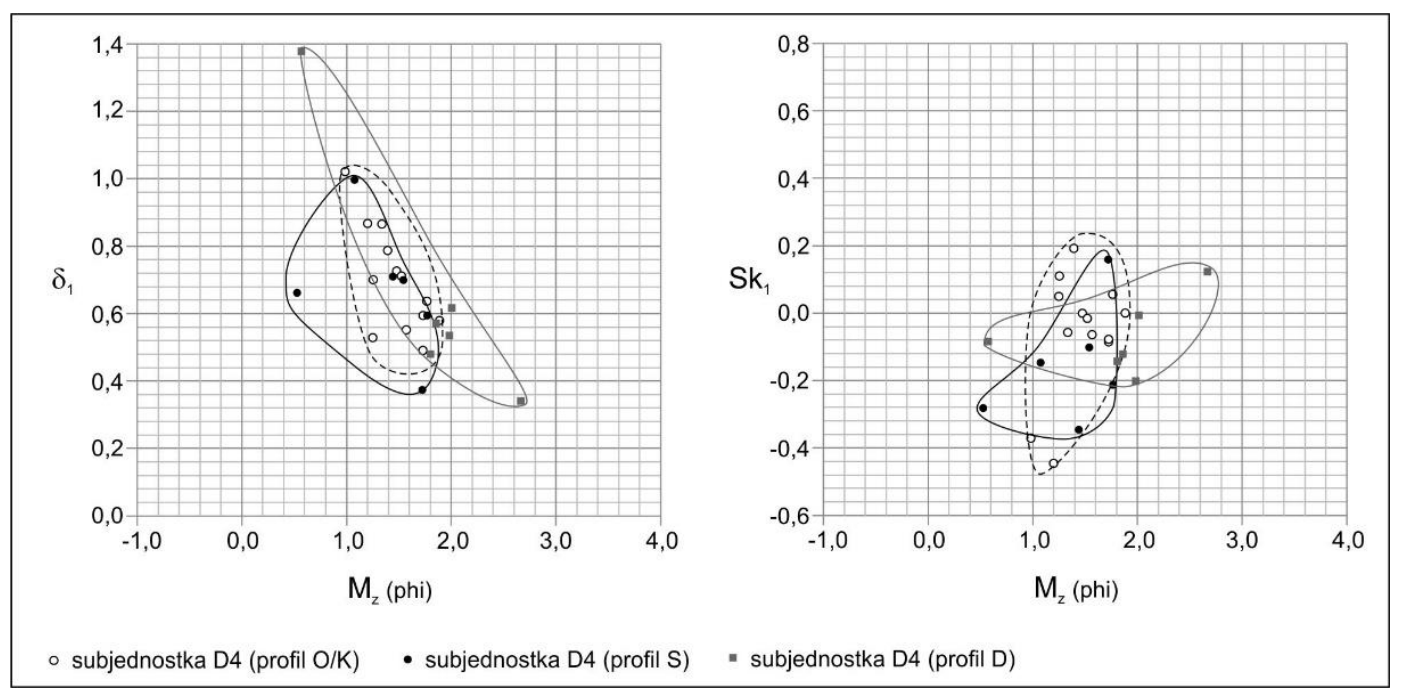

Rys. 6. Relacja średniej średnicy ziarna i wysortowania oraz średniej średnicy ziarna i skośności osadów subjednostki D4

Relationship between mean grain size and sorting degree and between mean grain size and skewness of deposits of the subunit D4 
Subjednostka D5 odróżnia się znacząco od subjednostki leżącej niżej, składa się z drobniejszego osadu, w przeważającej mierze odznaczającego się laminacją riplemarkową, choć pojawiały się warstwowania przekątne o niewielkiej skali oraz laminacja horyzontalna czy smużysta. Subjednostka D5 reprezentowana jest we wszystkich profilach. Jej miąższość w profilu S osiąga $6,4 \mathrm{~m}$, w profilu D 3,7 m, a najmniejsza jest w profilu $\mathrm{O} / \mathrm{K}$ i wynosi $1,8 \mathrm{~m}$ (rys. 2). Średnia średnica ziarna dla osadów z profilu $\mathrm{S}$ oscyluje między 1,467 a 2,982 phi, w profilu $\mathrm{D}$ między 1,839 a 2,969 phi, a w profilu $\mathrm{O} / \mathrm{K}$ wynosiła od 1,268 do 2,765 phi (rys. 2). W analizowanej subjednostce wyraźnie dominuje frakcja piasków drobnoziarnistych, chociaż udział piasków średnioziarnistych nie jest marginalny (rys. 7). Wysortowanie materiału jest dobre do średniego, na co wskazują wartości wskaźnika $\delta_{1}$ mieszczące się w granicach od 0,106 do $0,876 \mathrm{w}$ profilu $\mathrm{S}$, od 0,343 do 0,977 w profilu D i od 0,302 do 1,013 w profilu $\mathrm{O} / \mathrm{K}$. Skośność oscyluje w granicach od $-0,286$ do 0,194 w profilu $S$, od $-0,216$ do 0,212 w profilu D i od $-0,394$ do 0,204 w profilu O/K. Rozkład wartości miary skośności jest niemalże symetryczny, z niewielką przewagą przypadków, w których dominuje frakcja grubsza nad najczęściej występującą. Cechy granulometryczne subjednostki D5 w trzech badanych profilach są wyjątkowo zbieżne, a diagramy zależności średniej średnicy ziarna do wysortowania i średniej średnicy ziarna do skośności pokazują, że zdecydowana większość próbek mieści się we wspólnej grupie (rys. 7).

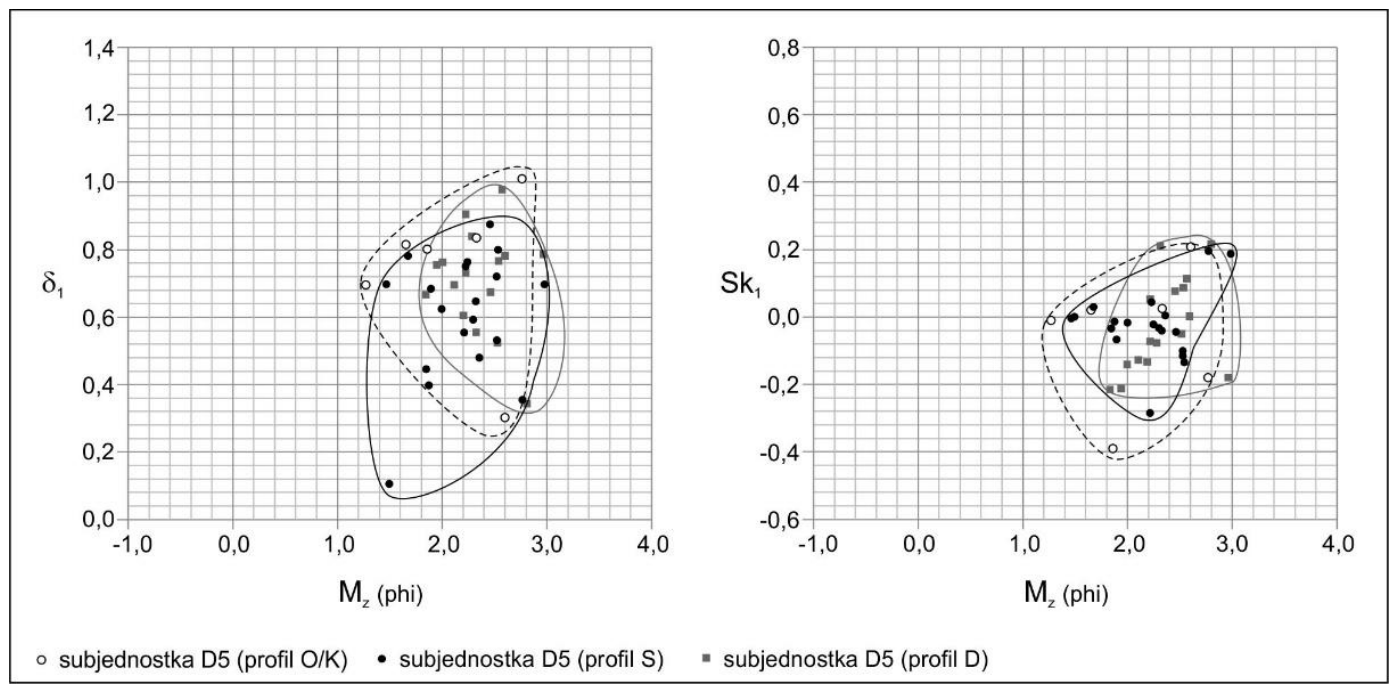

Rys. 7. Relacja średniej średnicy ziarna i wysortowania oraz średniej średnicy ziarna i skośności osadów subjednostki D5

Relationship between mean grain size and sorting degree and between mean grain size and skewness of deposits of the subunit D5

W subjednostce D5 występują inwolucje o małej skali od kilku do kilkunastu centymetrów. Mają charakter pogrązów przybierających postać zbliżoną do struktur kroplowych. Deformacje powstały na granicy cienkich przewarstwień mułowo-piaszczystych i warstw piaszczystych. Obecne są również ślady niewielkich, sezonowych szczelin mrozowych.

Subjednostka D6 zachowała się jedynie w profilu $\mathrm{D}$, gdzie osiąga miąższość $2,3 \mathrm{~m}$ (rys. 2). Osady jednostki warstwowane są przekątnie, przy czym skala struktur zmniejsza się ku stropowi, gdzie dominuje laminacja riplemarkowa i horyzontalna. Średnia średnica ziarna mieści się w granicach od 0,869 do 2,444 phi, a największa zmienność frakcji obserwowana jest w jej dolnej części. Najczęściej jednak wartości tego wskaźnika oscylują wokół 1,5 phi. Piaski są średnio lub dobrze wysortowane $(0,415-0,969)$, przy czym lepsze wysortowanie występuje w stropowej części jednostki. Skośność przyjmuje rozkład symetryczny, a wartości oscylują między $-0,229$ i 0,141 (rys. 2).

Kolejna jednostka $\mathrm{w}$ porządku stratygraficznym - jednostka E - reprezentowana jest przez serię organiczno-mineralną, obecną tylko w profilu $\mathrm{D}$, gdzie ma miąższość $0,7 \mathrm{~m}$. Seria ta odznacza się bardzo dużym rozprzestrzenieniem $\mathrm{w}$ terenie badań. Poddana była szczegółowym i wszechstronnym analizom (m.in. Dzieduszyńska $i$ in. 2014) 
i na podstawie kilkudziesięciu datowań radiowęglowych określono jej wiek (Dzieduszyńska, Twardy 2014). Jedno z datowań pochodziło ze stanowiska D, gdzie uzyskano wynik $10680 \pm 90$ ${ }^{14} \mathrm{C}$ BP (Lod 1396) (Petera-Zganiacz 2007).

$\mathrm{W}$ profilu $\mathrm{O} / \mathrm{K}$ wydzielono jednostkę $\mathrm{F}$, której osady wypełniają głębokie rozcięcie, warstwowane są przekątnie, a ich struktury mają dużą skalę. W spągu występują piaski średnioziarniste $\left(\mathrm{M}_{\mathrm{z}}\right.$ wynosi 1,7 phi), a ku stropowi przechodzą do piasków drobnoziarnistych $\left(\mathrm{M}_{\mathrm{z}}\right.$ równe 2,6 phi). Odznaczają się wysortowaniem średnim do dobrego i symetrycznym rozkładem skośności (rys. 2).

W górnej, dochodzącej do powierzchni terenu, części profili wydzielono jednostkę G. Ma ona odmienny charakter w profilach $\mathrm{O} / \mathrm{K} \mathrm{i} \mathrm{S}$, gdzie reprezentuje wypełnienia rozcięć erozyjnych, których powstanie poskutkowało usunięciem subjednostki D6 i jednostki E oraz w profilu $\mathrm{D}$, w którym jednostka $\mathrm{G}$ wykształcona jest w facji pozakorytowej. W osadach profili $\mathrm{O} / \mathrm{K}$ oraz S dominują warstwowania przekątne o różnej skali, natomiast osady w profilu D laminowane są riplemarkowo lub horyzontalnie (rys. 2).
W profilu $\mathrm{O} / \mathrm{K}$ średnia średnica ziarna w osadach jednostki $G$ oscyluje od 0,181 do 2,197 phi, w profilu $S$ od 0,165 do 2,197 phi, a w profilu $\mathrm{D}$ wartości tego wskaźnika mieszczą się między 2,38 a 3,75 phi (rys. 2, 8). Jednostkę wykształconą w facji korytowej reprezentują piaski średnio- i gruboziarniste, a nawet bardzo gruboziarniste dobrze lub średnio wysortowane (profil $\mathrm{O} / \mathrm{K}$ od 0,343 do 0,998 ; profil S od 0,334 do 0,928$)$. W profilu D jednostkę G tworzą piaski drobnoziarniste o wskaźniku wysortowania mieszczącym się zakresie tych samych stopni wysortowania jak w przypadku profili $\mathrm{O} / \mathrm{K}$ oraz S, jednak w tym przypadku wartości od 0,29 do 0,75 wskazują na lepsze wysortowanie. Zróżnicowanie dostrzega się również w skośności, większość próbek $\mathrm{z}$ profili $\mathrm{O} / \mathrm{K}$ i $\mathrm{S}$, pomimo wyników $\mathrm{w}$ granicach od $-0,233$ do $0,133 \mathrm{w}$ profilu $\mathrm{O} / \mathrm{K}$ i od $-0,158$ do $0,526 \mathrm{w}$ profilu $\mathrm{S}$, odznacza się skośnością ujemną. W profilu D skośność we wszystkich przypadkach jest dodatnia (od 0,08 do $0,35)$.

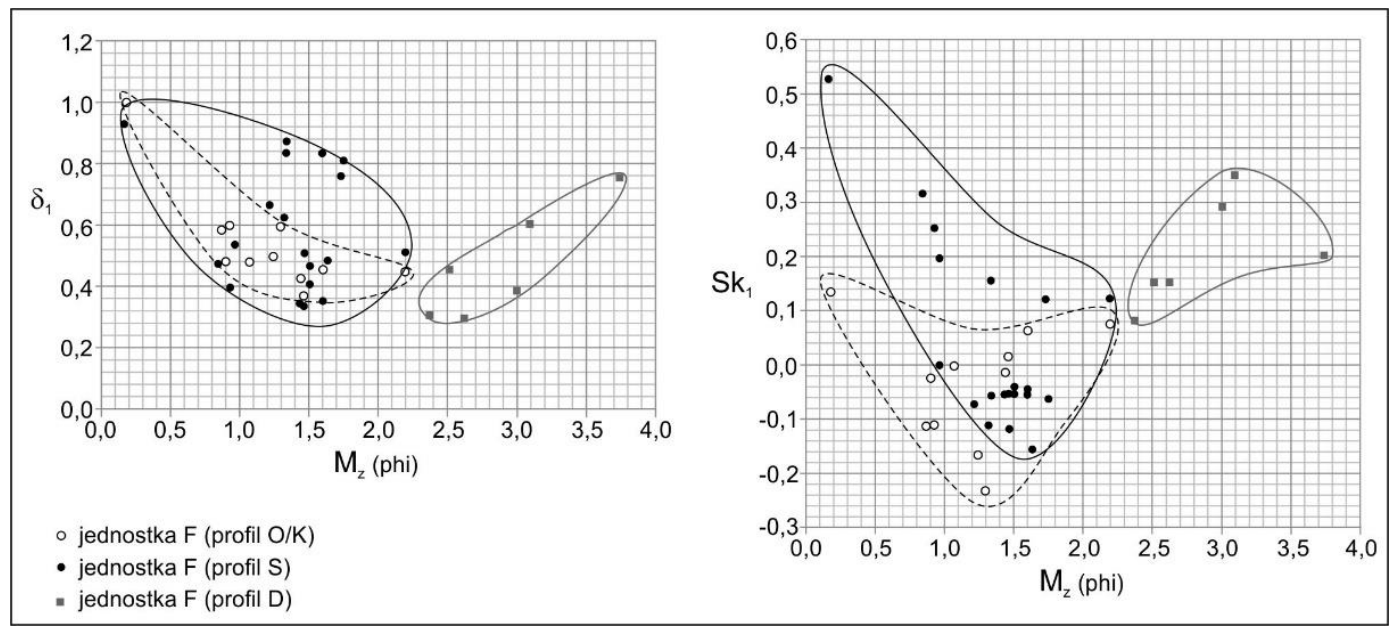

Rys. 8. Relacja średniej średnicy ziarna i wysortowania oraz średniej średnicy ziarna i skośności osadów jednostki $F$

Relationship between mean grain size and sorting degree and between mean grain size and skewness of deposits of the unit $\mathrm{F}$

\section{Interpretacja wyników i dyskusja}

Przeprowadzona analiza cech granulometrycznych osadów doliny Warty w wybranych profilach dostarcza szczegółowych danych, na podstawie których możliwe jest interpretowanie warunków panujących podczas ich depozycji. W pierwszej kolejności należy jednak dokonać przyporządkowania stratygraficznego analizowanych osadów. W badanym terenie sytuacja geologiczna jest dobrze rozpoznana, a wieloletnie badania prowadzone w odkrywkach PAK KWB „Adamów” dostarczyły dużą ilość danych pozwalających na względnie łatwą korelację nowych profili z już wcześniej udokumentowanymi.

Najstarsza $\mathrm{z}$ analizowanych jednostek (A) deponowana była najprawdopodobniej w środowisku fluwialnym. W profilu $\mathrm{O} / \mathrm{K}$ udokumento- 
wano wprawdzie tylko stropową część tej serii osadowej, ale jednostkę A można wiązać z miąższą serią piaszczystą podścielającą glinę warciańską udokumentowaną w odkrywce Koźmin-Północ. Powstała ona prawdopodobnie w warunkach zimnego klimatu w schyłkowej fazie interglacjału mazowieckiego lub w czasie zlodowacenia liwca jako miąższa, nawet na $20 \mathrm{~m}$, seria rzeczna akumulowana $\mathrm{w}$ środowisku sedymentacyjnym piaskodennej rzeki roztokowej (Czarnik 1972; Trzmiel 1996; Czubla i in. 2010, 2013).

Jednostkę A przykrywa cienka warstwa gliny zwałowej jednostki B. Rzędna spągu gliny nawiązuje do spągu gliny warciańskiej dolnej udokumentowanej w sąsiedniej odkrywce PAK KWB „Adamów” (Czubla i in. 2010, 2013). Glinę pokrywa rezyduum żwirowo-piaszczyste przypisane do jednostki $\mathrm{C}$, rejestrowane w miejscach, gdzie glina warciańska odznacza się zredukowaną miąższością lub nie występuje wcale. Okres kształtowania tej jednostki przypadł na schyłek zlodowaceń środkowopolskich (Trzmiel 1996; Petera 2002; Czubla i in. 2010).

$\mathrm{W}$ vistulianie akumulowana była najbardziej rozbudowana $\mathrm{z}$ analizowanych jednostek depozycyjnych - jednostka D. W dolinie Warty osady tego wieku stanowią ciągłą i miąższą serię osiągającą nawet $20 \mathrm{~m}$. Wynik datowania radiowęglowego (31 $\left.320 \pm 1050{ }^{14} \mathrm{C} \mathrm{BP}\right)$ pozwala zakładać, że początek akumulacji jednostki D miał miejsce w środkowym plenivistulianie. Zaznaczyć jednak trzeba, że rozważana sytuacja udokumentowana została w pobliżu osi doliny, podczas gdy w części dystalnej osady tego wieku odznaczają się mniejszą miąższością oraz obecnością kilku, dobrze wyrażonych i ciągłych poziomów organicznych (Klatowa i in. 1996; Petera 2002; PeteraZganiacz 2007).

Wydzielenie subjednostek depozycyjnych w obrębie jednostki D opiera się na założeniu, że odznaczają się one podobieństwem pod względem uziarnienia osadów, a zmienność pionowa w poszczególnych profilach wyraża powszechność tego zjawiska w osiowej części doliny. Na przykład podobieństwo cech granulometrycznych oraz obecność przewarstwień organicznych w subjednostce D1 na podobnym poziomie w profilach D i S daje dobre podstawy do ich korelowania, a bazując przede wszystkim na właściwościach uziarnienia, najlepiej korelują się osady subjednostek D4 i D5 obecne we wszystkich trzech profilach.

Zestawienie średniej średnicy ziarna i skośności dla całej populacji próbek z jednostki D (rys. 3), wskazuje, że znaczna większość przeba- danego materiału zawiera się $\mathrm{w}$ przedziale pola rozkładu osadów deponowanych w przejściowych warunkach reżimu przepływu (Szmańda 2011). Jednakże osady w profilu $\mathrm{O} / \mathrm{K}$ deponowane w przejściowych warunkach reżimu przepływu w 79\% przebadanych próbek posiadają cechy wykazujące na tendencję do górnego reżimu przepływu, a $12 \%$ do dolnego. Proporcje te układają się inaczej w profilach D i S - na przykład w profilu $\mathrm{S} 50 \%$ próbek wykazało cechy $\mathrm{z}$ tendencją do dolnego reżimu przepływu, a $41 \%$ populacji próbek do górnego. Diagram zależności średniej średnicy ziarna i wysortowania (rys. 3) ukazuje mało wyraziście układ 2b, odzwierciedlający pogorszenie wysortowania wraz ze zmniejszaniem się średniej średnicy ziarna $\mathrm{w}$ osadach bruku korytowego, następnie układ 1a, w którym widoczne jest polepszenie wysortowania wraz ze zmniejszeniem średniej średnicy ziarna właściwe dla osadów korytowych oraz układ 2a typowy dla osadów, których wysortowanie pogarsza się wraz ze zmniejszeniem frakcji akumulowanych w subśrodowisku pozakorytowym.

$\mathrm{Z}$ diagramu zależności wysortowania i średniej średnicy ziarna w subjednostce D1 (rys. 4.) wynika, że większość próbek z profili D i O/K oraz mniejsza część z profilu $\mathrm{S}$, nawiązując do układu 2a, wykazuje tendencje do pogorszenia wysortowania względem zmniejszania się średniej średnicy ziarna (wg Mycielskiej-Dowgiałło 1995 oraz Szmańdy 2011). W profilu S zaznacza się grupa próbek o bardzo zbliżonych wartościach średniej średnicy ziarna i różnym wysortowaniu. $\mathrm{Z}$ diagramu zależności skośności i średniej średnicy ziarna (rys. 4) wynika, że próbki głównie zawierają się $\mathrm{w}$ grupie właściwej dla przejściowych warunków reżimu przepływu, choć pojedyncze próbki z profili S i D odznaczające się najdrobniejszą frakcją wykazują cechy typowe dla dolnego reżimu przepływu. Depozycja subjednostki D1 zachodziła w warunkach równi zalewowej $\mathrm{w}$ zmiennych warunkach hydrodynamicznych, zdarzały się bowiem okresy spokojnej akumulacji głównie z zawiesiny, kiedy prędkość depozycyjna wynosiła kilka $\mathrm{cm} / \mathrm{s}$ oraz krótkotrwałe okresy wzmożonej dynamiki środowiska, w których była rzędu $10 \mathrm{~cm} / \mathrm{s}$ (Koster 1978; Szmańda 2011).

$\mathrm{Na}$ diagramie zależności wysortowania i średniej średnicy ziarna osadów subjednostki D2 w profilu $\mathrm{O} / \mathrm{K}$ wyraźnie zaznaczają się dwa układy 2b oraz 1a (wg Mycielskiej-Dowgiałło 1995 oraz Szmańdy 2011), wyniki dla profilu D nawiązują do układu 1a (rys. 5). Układ 2b wyraża pogorszenie wysortowania przy jednoczesnym 
zmniejszeniu średniej średnicy ziarna i świadczy o transporcie trakcyjnym lub saltacyjnym, odzwierciedlającym akumulację bruku korytowego. Depozycja następowała przy prędkości przekraczającej 25 cm/s (Koster 1978; Szmańda 2011). Układ 1a ukazuje polepszanie się wysortowania wraz ze zmniejszeniem frakcji oraz informuje o transporcie saltacyjnym i depozycji w korycie rzecznym przy prędkości między 25 a $10 \mathrm{~cm} / \mathrm{s}$ (Mycielska-Dowgiałło 1995; Szmańda 2011). Na znaczną dynamikę środowiska depozycyjnego, mieszczącą się w zakresie górnego reżimu przepływu, wskazują także dane z diagram zależności skośności i średniej średnicy ziarna (rys. 5).

Subjednostka D3 cechuje się depozycją osadu w warunkach dolnego reżimu przepływu. Wysortowanie osadów ulega pogorszeniu wraz z jego drobnieniem (rys. 2), co sugeruje, że transport deponowanego materiału odbywał się w sposób saltacyjny z udziałem transportu w zawiesinie.

Diagram zależności wysortowania i średniej średnicy ziarna dla subjednostki D4 pokazuje polepszanie się wysortowania wraz ze zmniejszeniem średniej średnicy ziarna, nawiązując do układu 1a (rys. 6), a rozkład wartości na diagramie relacji skośności i średniej średnicy ziarna jest typowy dla przejściowych warunków reżimu przepływu z tendencją do górnego reżimu (rys. 6). Materiał ten podlegał transportowi na drodze saltacji, akumulowany był $\mathrm{w}$ subśrodowisku korytowym przy prędkości depozycyjnej mieszczącej się w zakresie od 25 do $10 \mathrm{~cm} / \mathrm{s}$ (Mycielska-Dowgiałło 1995; Szmańda 2011).

Osady subjednostki D5 odznaczają się największym podobieństwem pod względem cech granulometrycznych we wszystkich trzech profilach (rys. 7). Świadczy to o jednorodnych warunkach sedymentacyjnych panujących $w$ dolinie. Dodać należy, że wartości poszczególnych wskaźników są skupione w niewielkiej, zwartej grupie. $\mathrm{Z}$ diagramu relacji skośności i średniej średnicy ziarna wynika, że osady zawierają się w przedziale właściwym dla przejściowych warunków reżimu przepływu, zarówno $\mathrm{z}$ tendencją do górnego, jak i dolnego reżimu. Na diagramie relacji wysortowania i średniej średnicy ziarna można zauważyć, że w osadach zaznacza się pogorszenie wysortowania przy równoczesnym zmniejszeniu średniej średnicy ziarna (rys. 7), ale jednocześnie możliwe jest wyodrębnienie populacji próbek, które wykazują tendencję odwrotną. Oznaczałoby to nakładanie się układu 1a na układ 2a. Wykształcenie układu 1a może wynikać $\mathrm{z}$ akumulacji drobnych, dobrze wysortowanych piasków przy nieznacznie większej prędkości depozycyjnej oraz piasków gorzej wysortowanych przy mniejszej prędkości. Można zakładać, że prędkość depozycyjna oscylowała wokół wartości $10 \mathrm{~cm} / \mathrm{s}$, a sposób transportu deponowanego materiału zmieniał się od wyłącznie saltacyjnego do saltacyjnego $\mathrm{z}$ udziałem transportu w zawiesinie (Koster 1978; Szmańda 2011).

Biorąc pod uwagę wyniki datowań radiowęglowych, należy stwierdzić, że jednostka D kształtowała się $\mathrm{w}$ okresie od nieco przed $31320 \pm 1050{ }^{14} \mathrm{C}$ BP do około $10680 \pm 90{ }^{14} \mathrm{C}$ BP, a więc od schyłku środkowego plenivistulianu po późny vistulian. Warunki depozycji w tym czasie ulegały zmianie - następowały okresy zwiększenia dynamiki środowiska fluwialnego i uspokojenia, kiedy akumulacja zachodziła nawet $\mathrm{z}$ zawiesiny. Należy zauważyć, że omawiana jednostka odznacza się znacznym rozprzestrzenieniem, a poszczególne subjednostki dają się dość wyraźnie wyodrębnić. W okresie formowania jednostki $\mathrm{D}$, przy założeniu, że istnieje w niej zapis całego okresu zamkniętego podanymi wyżej datami radiowęglowymi, panowały początkowo warunki dość surowego klimatu, od maksimum chłodu w apogeum ostatniego zlodowacenia, po stopniowe, choć nierównomierne ocieplania klimatu w późnym vistulianie. Następowały wtedy istotne zmiany $w$ dolinach rzecznych, polegające na przejściu od systemów o mniejszej sile transportowej (np.: Krzemiński 1965; Rotnicki 1987; Rotnicki, Młynarczyk 1989; Harasimiuk 1991; Superson 1996), wyrażonej w wielu przypadkach wykształceniem meandrowych (np.: Superson 1996; Goździk 1999) lub wielokorytowych układów koryt (van Huissteden 1990; Kasse i in. 1995a; Kasse 1998) do systemów o znacznie większych kompetencjach transportowych związanych $\mathrm{z}$ funkcjonowaniem powszechnie rzek roztokowych (np.: Rotnicki 1987; Turkowska 1988; Rotnicki, Młynarczyk 1989; Kamiński 1993; Harasimiuk 1991; Goździk 1999; Petera 2002; Wachecka-Kotkowska 2004; Forysiak 2005). Kolejnym etapem było zmniejszanie siły transportowej rzek i niesynchroniczne przechodzenie do układów wielkomeandrowych (np. Turkowska 1988; Rotnicki, Młynarczyk 1989; Kozarski 1991; Starkel 1991; Kalicki 1993; Kamiński 1993; Kasse i in. 1995b; Kobojek 2000) lub wielokorytowych (np. Superson 1996).

W analizowanych profilach cechy uziarnienia osadów jednostki D pokazują kilkakrotne, cykliczne zmiany dynamiki środowiska depozycyjnego od względnie wysokoenergetycznych warunków typowych dla koryt rzek roztokowych po mniej energetyczne warunki przejściowe (Zie- 
liński, Goździk 2001). Rzeki pozostające w stanie przejściowym deponują osady drobniejsze, o cechach uziarnienia podobnych do osadów facji pozakorytowej.

Istotna zmiana warunków depozycyjnych nastąpiła na granicy jednostki D i zalegających wyżej jednostek E, F i G. Przejście od jednostki D do mineralno-organicznej jednostki E miało charakter akumulacyjny, natomiast kontakt jednostki D z F i G ma charakter erozyjny, wyrażony głębokimi rozcięciami. Jednostka $G$ reprezentowana jest w profilach $\mathrm{O} / \mathrm{K}$ i S oraz D przez osady wykształcone w odmiennych warunkach hydrodynamicznych. Diagram relacji wysortowania i średniej średnicy ziarna pokazuje, że wysortowanie osadów w profilach $\mathrm{O} / \mathrm{K}$ i S polepsza się, przy równoczesnym zmniejszaniu się średniej średnicy ziarna (układ 1a), ale dla części próbek relacje wskaźników sugerują tendencje do tworzenia układu 2a, poprzez nieznaczne pogorszenie wysortowania w stosunku do zmniejszenia średniej średnicy ziarna (rys. 8). Prędkość depozycyjna dla tych osadów oscyluje w granicach 25-10 $\mathrm{cm} / \mathrm{s}$, a sposób transportu akumulowanego materiału był przede wszystkim saltacyjny z udziałem transportu w zawiesinie gradacyjnej (Szmańda 2011). W typowym układzie 2a grupują się próbki pochodzące $\mathrm{z}$ profilu $\mathrm{D}$, które nie tworzą części wspólnej z populacją próbek z pozostałych dwóch profili. Transport odbywał się na drodze saltacji i w zawiesinie, a osady deponowane były w środowisku odznaczającym się mniejszą dynamiką przy prędkości depozycyjnej mieszczącej się w granicach między 5 a $10 \mathrm{~cm} / \mathrm{s}$ (Koster 1978; Szmańda 2011). Z diagramu zależności skośności i średniej średnicy ziarna wynika, że w większości przypadków osady zawierają się w przedziale właściwym dla przejściowych warunków reżimu przepływu, przy czym $\mathrm{w}$ odniesieniu do profili $\mathrm{O} / \mathrm{K}$ i S zaznacza się tendencja do górnego reżimu (rys. 8). Odmienne cechy uziarnienia jednostki $\mathrm{G} w$ poszczególnych profilach, są wyrazem akumulacji w różnych subśrodowiskach depozycyjnych. W profilach $\mathrm{O} / \mathrm{K}$ i $\mathrm{S}$ występowało subśrodowisko korytowe $\mathrm{z}$ zapisem zapełniania koryt i zmniejszeniem dynamiki przepływu, a osady profilu D akumulowane były w subśrodowisku równi zalewowej. Analogiczne cechy uziarnienia osadów, tożsamych $\mathrm{z}$ wydzieloną w niniejszej pracy jednostką G, uzyskano w efekcie wcześniejszych badań (Twardy 2014; PeteraZganiacz i in. 2015).

Osady jednostki depozycyjnej G akumulowane były po około $10680 \pm 90{ }^{14} \mathrm{C}$ BP. Główny etap formowania jednostki przypadał na wczesną część młodszego dryasu, chociaż w sytuacjach, w których była reprezentowana przez fację korytową mogły nakładać się procesy zachodzące także w holocenie, nie wykluczając młodszego holocenu (Forysiak 2005; Petera-Zganiacz i in. 2015, w druku). W młodszym dryasie zaznaczyło się zwiększenie dynamiki procesów fluwialnych (np. Turkowska 1995; Starkel 2000; Kaiser i in. 2012) skutkujące $w$ wielu przypadkach powrotem do roztokowania (np.: Turkowska 1988; Kalicki 1991; Gębica 1995; Kasse i in. 1995b), a niekiedy tworzeniem się systemów wielokorytowych (Kalicki 1991; Forysiak 2005) jak miało to miejsce w badanym odcinku doliny Warty (Turkowska i in. 2000; Forysiak 2005; Petera-Zganiacz i in. 2015).

\section{Wnioski}

Przeprowadzone badania pozwalają na sformułowanie następujących wniosków:

1. Zróżnicowanie cech uziarnienia osadów wykazało, że wydzielenie jednostek i subjednostek depozycyjnych było uzasadnione, a skorelowanie ich między badanymi profilami dało podstawy do stwierdzenia, że odrębność poszczególnych jednostek wyraża zmiany zachodzące w środowisku depozycyjnym w kolejnych etapach akumulacji aluwiów, a nie zmiany subśrodowisk sedymentacyjnych $\mathrm{w}$ przestrzeni.

2. Najniższe $\mathrm{z}$ wydzielonych jednostek depozycyjnych (A, B i C) obejmują osady podłoża serii vistuliańskich, powiązane $\mathrm{z}$ kompleksem środkowopolskim. Zdefiniowanie pozycji stratygraficznej tych osadów pozwoliło na pewne wyznaczenie spągu osadów vistuliańskich, który znajduje się na rzędnej 80,2 m n.p.m. udokumentowanej w południowej części terenu badań profilu D i 79,5 m n.p.m. w zlokalizowanym niespełna $1,5 \mathrm{~km}$ na północny wschód profilu $\mathrm{O} / \mathrm{K}$.

3. W badanych profilach położonych w osiowej części doliny Warty osady vistuliańskie niemal całkowicie pozbawione są materii organicznej. Niewielki jej udział zaznacza się w spągu (subjednostka D1) i wyraźnie większy w górnej części profilu (jednostka E). Bezwzględna dominacja osadów mineralnych jest wyrazem surowych warunków środowiskowych, jakie panowały przez większość czasu depozycji osadów, który należy wiązać ze schyłkiem środkowego plenivistulianu i górnym plenvistulianem.

4. Depozycja vistuliańskich osadów fluwialnych ujętych $w$ jednostkę $\mathrm{D}$ zachodziła w przejściowych warunkach reżimu przepływu, 
ale w kolejnych subjednostkach, przynajmniej w trzech powtarzających się cyklach, zaznaczała się naprzemiennie tendencja do górnego i dolnego reżimu. Wskazuje to na zróżnicowane w czasie hydrodynamiczne warunki akumulacji osadów. Zintensyfikowanie procesów fluwialnych wyrażone było depozycją grubszych i lepiej wysortowanych osadów odkładanych w subśrodowisku korytowym, natomiast zmniejszenie ich intensywności wyrażało się przepływami o małej dynamice $\mathrm{z}$ silną tendencją do agradacji $\mathrm{w}$ warunkach bardzo płytkiego koryta. W takiej sytuacji właściwości uziarnienia osadów zbliżone były do cech osadów powodziowych.

5. Najmłodszy etap depozycji osadów vistuliańskich w dolinie Warty wyrażony jest akumulacją najbardziej zróżnicowanego frakcjonalnie materiału odkładanego na równi zalewowej i w trwałych, wyraźnie wyodrębniających się korytach, formujących układ wielokorytowy podczas młodszego dryasu.

6. Dobrze poznany podczas wcześniejszych badań obraz formowania aluwiów w dystalnej części doliny Warty uzupełniony został o nowe dane, które pozwoliły na rekonstrukcję warunków depozycji osadów w proksymalnej, bardzo szerokiej w Kotlinie Kolskiej, części doliny.

\section{Podziękowania}

Autorzy składają podziękowania recenzentkom: dr hab. Elżbiecie Kobjek prof. UŁ oraz dr hab. Lucynie Wacheckiej-Kotkowskiej oraz redakcji czasopisma za cenne uwagi do tekstu.

\section{Literatura}

Brodzikowski K. 1992. Rola i zakres sedymentologicznych badań litofacjalnych w geologii i geomorfologii glacjalnej. W: K. Brodzikowski, T. Zieliński, B. Gruszka (red.) Problemy sedymentacji glacilimnicznej. Materiały letniej szkoły sedymentologicznej. Murzynowo wrzesień 1992: 7-56.

Czarnik J. 1972. Paleogeografia okolic Turka w górnym trzeciorzędzie i plejstocenie. Studia Geologica Polonica 40: 1-165.

Czubla P., Forysiak J., Petera-Zganiacz J. 2010. Lithologic and petrographic features of tills in the Koźmin region and their value for stratigraphical interpretation of the deposits of the Koźmin glacial lake, central Poland. Geologija 52(1-4): 1-8.

Czubla P., Forysiak J., Petera-Zganiacz J., Grajoszek M., Wiśniewska M. 2013. Charakterystyka li- tologiczno-petrograficzna osadów czwartorzędowych w dolinie Warty (stanowisko Koźmin-Północ). Przegląd Geologiczny 61(2): 120126.

Dzieduszyńska D., Twardy J. 2014. Ogólna charakterystyka stanowiska Koźmin Las. Acta Geographica Lodziensia 102: 11-21.

Dzieduszyńska D.A., Kittel P., Petera-Zganiacz J., Brooks S.J., Korzeń K., Krąpiec M., Pawłowski D., Płaza D.K., Płóciennik M., Stachowicz-Rybka R., Twardy J. 2014. Environmental influence on forest development and decline in the Warta River valley (Central Poland) during the Late Weichselian. Quaternary International 324: 99-114.

Folk R.L., Ward W.C. 1957. Brazos River bar: a study in the significance of grain size parameters. Journal of Sedimentary Petrology 27: 3-26.

Forysiak J. 2005. Rozwój doliny Warty między Burzeninem a Dobrowem po zlodowaceniu warty. Acta Geographica Lodziensia 90: 1-116.

Gębica P. 1995. Ewolucja doliny Wisły pomiędzy Nowym Brzeskiem a Opatowcem w vistulianie i holocenie. Dokumentacja Geograficzna PAN 2: 1-91.

Gilewska S. 1991. Współczesne środowisko przyrodnicze. Rzeźba. W: L. Starkel (red.) Geografia Polski. Środowisko przyrodnicze. Wyd. Nauk. PWN, Warszawa: 248-296.

Goździk J.S. 1995. Wpływ procesów eolicznych na genezę górnoplenivistuliańskich aluwiów w Środkowej Polsce. Acta Universitatis Lodziensis, Folia Geographica 20: 99-108.

Goździk J.S. 1999. Sediments of periglacial environment from Pleistocene deposits in the Bełchatów opencast mine. Łódź Periglacial Symposium „Periglacial Environments: Past, Present and Future", Łódź 27-30 September 1999, Exc. III: 75-82.

Goździk J.S., Zieliński T. 1999. Plenivistulian and Late Vistulian sediments of the Struga Żłobnicka series - a characteristic example of valley infill in central Poland. Łódź Periglacial Symposium „Periglacial Environments: Past, Present and Future", Łódź 27-30 September 1999, Exc. III: 82-84.

Harasimiuk M. 1991. Vistulian glacial cycle of the fluvial processes development in the valley of the middle Wieprz River (SE Poland). Annales UMCS 46: 81-109.

Kaiser K., Lorenz S., Germer S., Juschus O., Küster M., Libra J, Bens O., Hütti R.F. 2012. Late Quaternary evolution of rivers, lakes and peatlands in northeast Germany reflecting past climates and human impact - an overview. E\&G Quaternary Science Journal 61: 103132.

Kalicki T. 1991. The evolution of the Vistula river valley between Cracow and Niepołomice in 
Late Vistulian and Holocene times. Geographical Studies, Special Issue 6: 11-37.

Kalicki T. 1993. Studia nad późnoglacjaną i holoceńską ewolucją wybranych dolin rzecznych na Białorusi. Folia Geographica Ser. Geogr.Phys. 24/25: 73-84.

Kamiński J. 1993. Późnoplejstoceńska i holoceńska transformacja doliny Moszczenicy. Acta Geographica Lodziensia 64: 1-104.

Kasse C. 1998. Depositional model for cold - climate tundra rivers. W: G. Benito, V.R. Baker, K.J. Gregory (red.) Paleohydrology and Environmental Change. Willey and Sons, Chichester: 83-97.

Kasse C., Bohncke S.J.P., Vandenberghe J. 1995a. Fluvial periglacial environments, Climate and vegetation during the Middle Weichselian in the northen Netherlands with special Reference to the Hengelo Interstadial. Mededelingen Rijks Geological Dienst 52: 387-414.

Kasse C., Vandenberghe J., Bohncke S.J.P. 1995b. Climatic change and fluvial dynamics of the Maas during the late Weichselian and early Holocene. Palaoklimaforschung/Palaeoclimate Research 14: 123-150.

Klatkowa H., Załoba M., Forysiak J. 1996. Nowy profil osadów plejstoceńskich i holoceńskich w środkowej Polsce. III Konferencja „Stratygrafia plejstocenu Polski“, Wigry: 17.

Kobojek E. 2000. Morfogeneza doliny Rawki. Acta Geographica Lodziensia 77: 1-157.

Koster E.H. 1978. Transverse rib; their characteristics, origin and paleohydrologic significance. W: A.D. Miall (red.) Fluvial sedimentology. Can. Soc. Petrol. Mem. 5: 161-186.

Kozarski S. 1983. River channel changes in the middle reach of the Warta Valley, Great Poland Lowland. Quaternary Studies in Poland 4: 159-169.

Kozarski S. 1991. Warta - a case of a lowland river. W: L. Starkel, K.J. Gregory, J.B. Thornes (red.) Temperate paleohydrology. Wiley and Sons, Chichester: 189-215.

Krzemiński T. 1965. Przełom doliny Warty przez Wyżynę Wieluńską. Acta Geographica Lodziensia 21: 1-95.

Krzyszkowski D. 1990. Middle and Late Weichselian stratigraphy and palaeoenvironments in central Poland. Boreas 19: 333-350.

Lisek M. 2017. Interpretacja sedymentologiczna osadów doliny Warty w okolicach Koźmina. Maszynopis pracy magisterskiej, Katedra Geomorfologii i Paleogeografii WNG UŁ.

Manikowska B. 1996. Dwucykliczność ewolucji środowiska peryglacjalnego w Polsce Środkowej podczas Vistulianu. Biuletyn Państwowego Instytutu Geologicznego 373: 97-106.

Marks L., Ber A., Gogołek W., Piotrowska K. (red.) 2006. Mapa geologiczna Polski 1:500 000. Państwowy Instytut Geologiczny, Warszawa.
Mycielska-Dowgiałło E. 1995. Wybrane cechy teksturalne osadów i ich wartość interpretacyjna. W: E. Mycielska-Dowgiałło, J. Rutkowski (red.) Badania osadów czwartorzędowych. Wydział Geografii i Studiów Regionalnych Uniwersytetu Warszawskiego: 220-235.

Mycielska-Dowgiałło E., Ludwikowska-Kędzia M. 2011. Alternative interpretations of grain-size data from Quaternary deposits. Geologos 17(4): 189-203.

Pazdur M., Stankowski W., Tobolski K. 1980. Litologiczna i stratygraficzna charakterystyka profilu z kopalnymi utworami organogenicznymi w Malińcu koło Konina. Badania Fizjograficzne nad Polska Zachodnia 33: 79-88.

Petera J. 2002. Vistuliańskie osady dolinne w basenie uniejowskim i ich wymowa paleogeograficzna. Acta Geographica Lodziensia 83: 1-174.

Petera-Zganiacz J. 2007. Osady rzeki plenivistuliańskiej w Koźminie. Acta Geographica Lodziensia 93: 43-56.

Petera-Zganiacz J., Dzieduszyńska D.A., Twardy J., Pawłowski D., Płóciennik M., Lutyńska M., Kittel P. 2015. Younger Dryas flood events: A case study from the middle Warta River valley (Central Poland). Quaternary International 386: 55-69.

Petera-Zganiacz J., Piotrowska M., Twardy J., Dzieduszyńska D., Okupny D., Forysiak J., Rzepecki S. w druku. Environmental conditions as a key factor in the functioning of wells at a settlement from the Roman period of the Iron Age. Quaternary International https://doi. org/10.1016/j.quaint.2017.08.046

PN-R-04032 1998. Gleby i utwory mineralne - pobieranie próbek i oznaczanie składu granulometrycznego. PKN.

Rotnicki K. 1987. Main phases of erosion and accumulation in the Prosna Valley in the last glacial - interglacial cycle. Geographia Polonica 53: 53-65.

Rotnicki K., Młynarczyk Z. 1989. Późnovistuliańskie i holoceńskie formy i osady korytowe środkowej Prosny i ich paleohydrologiczna interpretacja. Wyd. Nauk. UAM, Seria Geografia 43: $1-76$.

Rutkowski J. 1995. O opróbowaniu i reprezentatywności wyników w badaniach litologicznych. W: E. Mycielska-Dowgiałło, J. Rutkowski (red.) Badania osadów czwartorzędowych. Wydział Geografii i Studiów Regionalnych Uniwersytetu Warszawskiego: 9-29.

Stankowski W., Krzyszkowski D. 1991. Stratygrafia czwartorzędu okolic Konina. W: W. Stankowski (red.) Przemiany środowiska geograficznego obszaru Konin-Turek. Instytut Badań Czwartorzędu UAM, Poznań: 11-31.

Starkel L. 1991. The Vistula River Valley: a case study for Central Europe. W: L. Starkel, K.J. Gregory, J.B. Thorne (red.) Temperate paleo- 
hydrology. Wiley and Sons, Chichester: 171188.

Starkel L. 2000. Chronology of phases of various fluvial activity, of erosion and deposition in the Vistula catchment during the Late Quaternary. Geochronometria 19: 53-58.

Superson J. 1996. Funkcjonowanie systemu fluwialnego wyżynnej części dorzecza Wieprza w zlodowaceniu wisły. Wyd. UMCS, Wydział Biologii i Nauk o Ziemi. Rozprawy habilitacyjne 53: 1-280.

Szmańda J.B. 2011. Zapis warunków depozycji w uziarnieniu aluwiów pozakorytowych. Landform Analysis 18: 1-9.

Trzmiel B. 1996. Objaśnienia do Szczegółowej mapy geologicznej w skali 1:50 000, ark. Turek (550). PIG, Warszawa: 1-47.

Turkowska K. 1988. Rozwój dolin rzecznych na Wyżynie Łódzkiej w późnym czwartorzędzie. Acta Geographica Lodziensia 57: 1-157.

Turkowska K. 1990. Main fluvial episodes in the Ner Valley in the last 22000 years; a detail study in Lublinek near Łódź, Central Poland. Quaternary Studies in Poland 9: 85-99.

Turkowska K. 1995. Recognition of valleys evolution during the Pleistocene-Holocene transition in non-glaciated regions of Polish Lowlands. Biuletyn Peryglacjalny 34: 209-227.

Turkowska K. 1997. Stan wiedzy na temat rozwoju dolin ekstraglacjalnych na Niżu Polskim w okresie przejściowym plejstocen-holocen. Acta Universitatis Lodziensis, Folia Geographica Physica 1: 67-87.

Turkowska K. 2006. Geomorfologia regionu łódzkiego. Wyd. UŁ, Łódź: 1-238.

Turkowska K., Petera J., Forysiak J., Miotk-Szpiganowicz G. 2000. Morfogeneza powierzchni Kotliny Kolskiej w okolicach Koźmina. Acta Geographica Lodziensia 78: 98-134.

Twardy J. 2014. Litologiczna charakterystyka osadów w stanowisku Koźmin Las i ich interpretacja paleogeograficzna. Acta Geographica Lodziensia 102: 23-38.

van Huissteden J. 1990. Tundra rivers of the last glacial: sedimentation and geomorphological processes during the Middle Pleniglacial in Twente, eastern Netherlands. Mededelingen Rijks Geological Dienst 44(3): 1-138.

Wachecka-Kotkowska L. 2004. Ewolucja doliny Luciąży - uwarunkowania klimatyczne a lokalne. Acta Geographica Lodziensia 86: 1-161.

Zieliński T., Goździk J. 2001. Palaeoenvironmental interpretation of a Pleistocene alluvial succession in central Poland: sedimentary facies analysis as a tool for palaeoclimatic inferences. Boreas 30: 240-253.

\section{Summary}

The features of fluvial deposits, which were accumulated during the Vistulian, are very well recognized in many river valleys of the Polish Lowlands. The studies were usually carried out in open pits located on river terraces and were met with obvious technical restrictions. The presented studies were conducted due to the possibility of analysing fluvial deposits of a big lowland river close $(500 \mathrm{~m})$ to the axis of the valley. That exceptional condition occurred in the open pits Koźmin North (Kwiatków) and Koźmin (South) of the „Adamów” Lignite Mine.

The study area was located in the southwestern part of the Koło Basin, where the main geomorphological element is the Warta River valley. In the valley, a wide lower terrace dominates, divided into isolated patches by numerous streams, mostly dry nowadays. The analysis was conducted in the open pits located on the lower terrace. Two of the selected profiles $(\mathrm{O} / \mathrm{K}$ and $\mathrm{S})$ were studied in the Koźmin North (Kwiatków) open pit and one (D) in the Koźmin (South) open pit. The aim of the investigations was the recognition of selected textural features of deposits, and establishing the phases of deposition and hydrodynamic conditions during the accumulation on the base of grain size analysis and Folk and Ward coefficients.

In the studied profiles, seven depositional units have been distinguished (A, B, C, D, E, F and $G$ ). The thickest unit $D$ was divided into seven subunits. The basis of the division was grain size composition and basic structural features. Units $\mathrm{A}, \mathrm{B}$ and $\mathrm{C}$ were deposited during the Middle Polish Complex and represent the background of the unit D - the lowest Vistulian unit - documented in the analysed profiles.

Unit D developed during the period from the end of the Middle Plenivistulian to the Late Vistulian, which was identified on the basis of radiocarbon datings obtained from organic-rich layers occurring in subunit D1 $\left(31320 \pm 1050{ }^{14} \mathrm{C}\right.$ $\mathrm{BP})$ and unit $\mathrm{E}\left(10680 \pm 90{ }^{14} \mathrm{C} \mathrm{BP}\right)$ which covers unit D. Subunits D0, D2 and D4 mainly consist of medium sand, well or medium sorted with negative skewness. The dependency diagrams of the mean grain size and sorting degree as well as dependency diagrams of the mean grain size and skewness allow to conclude that accumulation took place under transitional energy flow regime with tendencies towards the high regime. The grains were transported in saltation and settlement velocities range from 25 to 10 
$\mathrm{cm} / \mathrm{s}$. Subunits D1, D3 and D5 are dominated by fine sand usually well or medium sorted with positive skewness in most cases, but in the subunit D5 negative skewness predominates. The deposition of that subunit took place under transitional energy flow regime, but with slight tendencies towards the low regime. The movement of grains took place in saltation and suspension, the settlement velocitie value was about $10 \mathrm{~cm} / \mathrm{s}$. Subunit D6 joins the features of both groups of subunits.

The deposition of unit $\mathrm{D}$ was characterized by cyclic, but rather mild transitions from rather high energetic to the low energetic conditions. The changes were probably common in the axis part of the Warta River valley and they reflected the tendencies in the valley development during the part of Vistulian.

Unit $\mathrm{F}$ is probably an element of transition towards the development of unit $\mathrm{G}$, which was accumulated through the Younger Dryas and Holocene in two clearly distinguishing facies: channel and overbank, with high content of organic matter, but only in Holocene channels fillings. Channel deposits have had a flow energy regime typical for transitional with tendencies toward high flow regime grain size parameters: medium to coarse sand, well or medium sorting degree and negative skewness. Overbank deposits consist of fine sands, medium and well sorted with positive skewness. The flow energy regime was transitional with tendencies to low regime.

The features of the studied deposits of unit $D$ reflect changes of the sedimentary environment from typical braided river to transitional river in at least three cycles, while the character of the deposits documented in unit $\mathrm{G}$ indicates development of deposits in stable channels and clearly defined floodplain. 